\title{
AWRA-G: A groundwater component for a continental scale land surface model
}

\author{
$\underline{\text { R.S. Crosbie }}^{\text {a }}$, L. Peeters ${ }^{\text {a }}$, R.C. Doble ${ }^{\text {a }}$, K. Joehnk ${ }^{\text {a }}$, E. Carrara ${ }^{\text {b }}$, C. Daamen ${ }^{\text {b }}$ and A. Frost ${ }^{\text {b }}$ \\ ${ }^{a}$ Water for a Healthy Country National Research Flagship, CSIRO Land and Water \\ ${ }^{b}$ Climate and Water Division, Bureau of Meteorology \\ Email: russell.crosbie@,csiro.au
}

\begin{abstract}
The Australian Water Resources Assessment (AWRA) system of models is currently being developed by CSIRO for BOM under the Water Information Research and Development Alliance (WIRADA) to enable BOM to meet its requirements under the Water Act 2007 for undertaking annual water resource assessments and national water accounts. AWRA consists of several linked component models, namely: AWRA-L, a landscape model; AWRA-R, a river routing model; and, AWRA-G, a groundwater component model. AWRA is a hind-casting model; it can use observations of available elements of the water balance to inform other components for which no data exists.
\end{abstract}

Most continental scale land surface models do not have the capacity to allow water to flow between cells as groundwater and so misrepresent this element of the water balance. The conceptualisation of groundwater within AWRA-L is consistent with other continental scale landscape models in that recharge and discharge occur within the same grid cell. This is likely to be a suitable assumption in upland areas with local groundwater flow systems but is not appropriate for regional systems. The sources of groundwater storage changes that are not accounted for in AWRA-L are from groundwater extraction, losing streams, overbank flooding, flow from adjacent cells, discharge to the ocean and interactions between the surficial aquifer and deep confined systems.

Groundwater extraction is accounted for in AWRA-G through the metering or estimation of extraction within a grid cell of AWRA-L. This information is to be collected by BOM as part of their regulations data under the Water Act 2007.

Recharge from losing streams is accounted for within the node-link AWRA-R model. The losses from the river are accounted for at a reach scale and then need to be apportioned in space back to the gridded landscape model. Once this recharge is added back into the landscape model it is then available to be transpired by vegetation or extracted via pumping.

Recharge from overbank flooding is estimated from open water likelihood mapping derived from MODIS imagery combined with floodplain soil type, aquifer transmissivity and depth to water table. The finer scale estimates of recharge on the MODIS grid $(\sim 500 \mathrm{~m})$ are then aggregated to the AWRA-L grid $(\sim 5 \mathrm{~km})$ for each time step.

Groundwater flow between AWRA-L cells is estimated using Darcy's Law from modelled water table surface derived from AWRA-L, this will be supplemented with groundwater level observations through data assimilation. Groundwater discharge to the ocean is treated similarly.

The fluxes from groundwater extraction, losing streams, overbank flooding, lateral flow and ocean discharge are aggregated at the AWRA-L grid cell scale by AWRA-G and then passed to the groundwater storage bucket within AWRA-L for each time step.

The AWRA system of models (including AWRA-G) will provide, for the first time, the ability to model the water balance at a continental scale with the accuracy required to report results at a local scale.

Keywords: Groundwater, Landscape, Model 
Crosbie et al., AWRA-G: A groundwater component for a continental scale land surface model

\section{INTRODUCTION}

Most land surface models have a very simplified groundwater conceptualisation (if groundwater is even considered); often it is assumed to be a 1-D system that causes groundwater recharge to become baseflow within the same grid cell (Gulden et al., 2007; Kowalczyk et al., 2006; Liang et al., 2003; Oleson et al., 2010). There is a growing acknowledgement that a more physically based conceptualisation of groundwater within land surface models will produce more realistic results (Fan and Miguez-Macho, 2011; Maxwell and Kollet, 2008).

This paper will present the conceptualisation for a simple groundwater component model for incorporation into an existing continental scale land surface model.

\section{AWRA SYSTEM OF MODELS}

AWRA-G is the groundwater component of the AWRA system of models. The other model components of AWRA are a land surface model (AWRA-L) and a river routing model (AWRA-R). These three component models combined are expected to be able to model the fluxes and stores of water throughout the landscape at a continental scale. This model will be used by BOM in their National Water Accounts and Water Resource Assessment where the water balance is reported at a regional scale, as this is retrospective reporting AWRA is a hindcasting model and so is not required to make predictions of future water balances.

AWRA-G was designed to provide estimates of groundwater fluxes that are not incorporated into either AWRA-L or AWRA-R. The algorithms behind AWRA-L are described in van Dijk (2010) and modifications made to the soil and groundwater processes are described in Peeters et al (2011). The groundwater processes that are incorporated into AWRA-L are:

- Diffuse groundwater recharge (water infiltrating past the root zone into the groundwater store)

- Diffuse groundwater discharge (discharge to the atmosphere via evaporation or transpiration)

- Baseflow (groundwater discharge to streams)

- Lateral re-distribution within a grid cell (groundwater is only discharged from the low points in the landscape)

- Groundwater storage

AWRA-R is described in Frost et al (2011) and Leighton et al (2011). AWRA-R has an allowance made for surface water - groundwater interactions; this includes the river gains and losses to groundwater.

The groundwater processes identified that are not incorporated into AWRA-L or AWRA-R that have been included in AWRA-G are:

- Groundwater extraction (pumping, also injection if significant)

- Lateral groundwater flow between AWRA-L cells in regional groundwater systems

- Distribution of river losses to groundwater (from AWRA-R)

- Recharge from overbank flooding

- Groundwater discharge to the ocean

- Interactions between deep confined systems and surficial groundwater systems

AWRA-G has various components that estimate the fluxes identified above and accumulate them into a single flux for each time step (daily) that is added to or subtracted from the groundwater store in AWRA-L (see Figure 1). AWRA-L currently has a groundwater store that sits below the three soil stores, AWRA-G will not have its own groundwater store. AWRA-G is not intended as a groundwater management model that is capable of replacing the likes of MODFLOW; AWRA-G is a groundwater component for a land surface model. It is not a groundwater model in its own right; it consists of a series of processes that work on the groundwater store within the AWRA-L framework. 


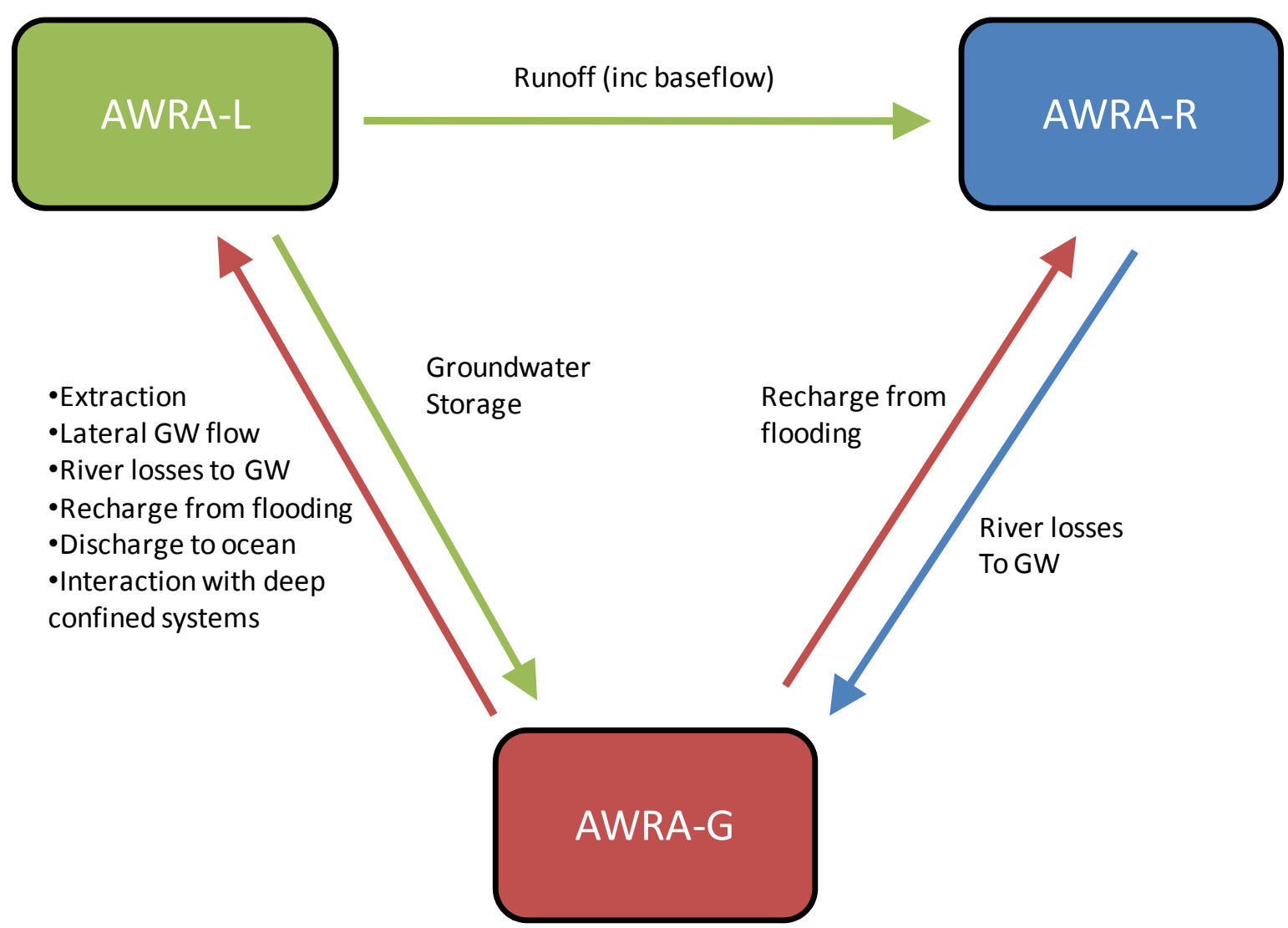

Figure 1. Conceptual flow of information between AWRA components. (Arrows represent flow of information between models not the direction of water fluxes).

\section{AWRA-G MODEL COMPONENTS}

\subsection{Groundwater extraction}

Groundwater extraction should be simple to account for. Ideally the extraction data will be held in AWRIS (Australian Water Resources Information System) with spatial information from NGIS (National Groundwater Information System). This should be able to be queried to provide a grid $\left(0.05^{\circ}\right)$ of groundwater extractions that can be read in AWRA. Currently this is not possible and probably will not be possible before AWRA-G is implemented.

Until this functionality exists, groundwater extraction will be calculated manually. If extraction data is available (metered or estimated) then it is most likely to be an annual accumulation. AWRA runs on a daily time step and so this data will need to be temporally disaggregated. At its simplest, this would be a constant pumping rate throughout the irrigation season. This is how extraction for irrigation is treated within the MODFLOW groundwater management models developed by the jurisdictions and these will be used as guidance to begin with.

\subsection{Lateral groundwater flow}

AWRA-L does not allow groundwater to flow between grid cells and so this will be estimated via AWRA-G. Not all groundwater flow systems (GFS) will require lateral flow between cells to be estimated. In local GFS the recharge and discharge points are close together and so the groundwater flow paths are short, in these areas it can be assumed that there is no flow between AWRA grid cells. In regional GFS the flow paths can be up to 1000's of kilometers and so lateral flow between grid cells might be an important process.

Calculating the lateral flow is a relatively simple process, via an application of Darcy's Law:

$$
\mathrm{Q}=\mathrm{kiA}
$$

where $\mathrm{Q}$ is the flow $\left[\mathrm{L}^{3} / \mathrm{T}\right], \mathrm{k}$ is the hydraulic conductivity $[\mathrm{L} / \mathrm{T}], \mathrm{i}$ is the hydraulic gradient $[-]$ and $\mathrm{A}$ is the cross sectional area $\left[\mathrm{L}^{2}\right]$. The hydraulic gradient is estimated as the slope of the water table from a water table map, $\mathrm{k}$ will eventually come from NGIS and A is the saturated thickness of the aquifer multiplied by the 
width of an AWRA grid cell; the saturated thickness of the aquifer will also eventually come from NGIS. Until this is possible the saturated thickness of the aquifer and the hydraulic conductivity can be taken from calibrated groundwater models that are most likely to exist in areas that are important for regional flow.

It is yet to be determined where in Australia that regional groundwater flow is likely to be important and so a method needs to be developed to determine this. This will involve a groundwater characterization process to determine like GFS. As a first cut this could involve a classification such as that described by Crosbie et al (2008):

- Upland fractured rock areas

- Shallow river valley alluvial systems

- Regional alluvial / sedimentary systems

- Confined systems

- Fossil water resources

The upland fractured rock systems (e.g. Lachlan Fold Belt) would be excluded from the calculation of lateral flow as it can be assumed that the flow paths are too short to generate flow between cells. The shallow river valley alluvial systems (e.g. Bell River, Belubula River) generally have very well connected surface and groundwater resources, to the point where groundwater extraction is pumping water out of the river. The GW-Link module (Rassam, 2011) within Source Rivers (AWRA-R) (Welsh et al., 2011) was designed to account for these groundwater systems within the river model and so these systems can be excluded from the calculation of lateral flows in AWRA-G. The regional alluvial / sedimentary systems (e.g. Murray Basin) are the target of the estimation of lateral flows within AWRA-G, these systems are important sources of water where the recharge and discharge locations can be separated by large distances. The confined systems (e.g. GAB) are considered separately within this paper, see 3.6. The Fossil water resources (e.g. Paleochannels in the WA goldfields) are groundwater resources leftover from a wetter period in geologic history, they are assumed to not be receiving modern recharge and generally not be flowing anywhere, they can also be excluded from this process.

A key input into this classification would be the GFS mapping (Coram et al., 2000). This has disaggregated the country into three broad groupings (and more sub-groupings): local flow systems, intermediate flow systems and regional flow systems (Figure 2). It is the regional GFS from this mapping that will be considered for the calculation of lateral flows as a local GFS is defined as having a flow path of less than 5 $\mathrm{km}$ which is approximately the size of an AWRA grid cell. Initially this work will focus upon areas where we have a chance of mapping the water table surface with some reliability, this could include: Murray Basin, Darling Basin, Perth Basin, Otway Basin and the Victorian Volcanic Plains.

The water table map necessary for calculation of the hydraulic gradients will be calculated from the groundwater storage and elevation from AWRA-L. As AWRA-L runs on a daily time step this will enable the lateral flow to be calculated daily, however, groundwater moves very slowly and so the changes in lateral flow on a daily basis may not be large enough to warrant the computational burden of daily changes being calculated. It will be investigated whether the lateral flows can be calculated quarterly and then applied daily. There are also plans for the assimilation of an interpolated water table surface from observation bores into AWRA-L, as the monitoring frequency of many bore networks is quarterly. 


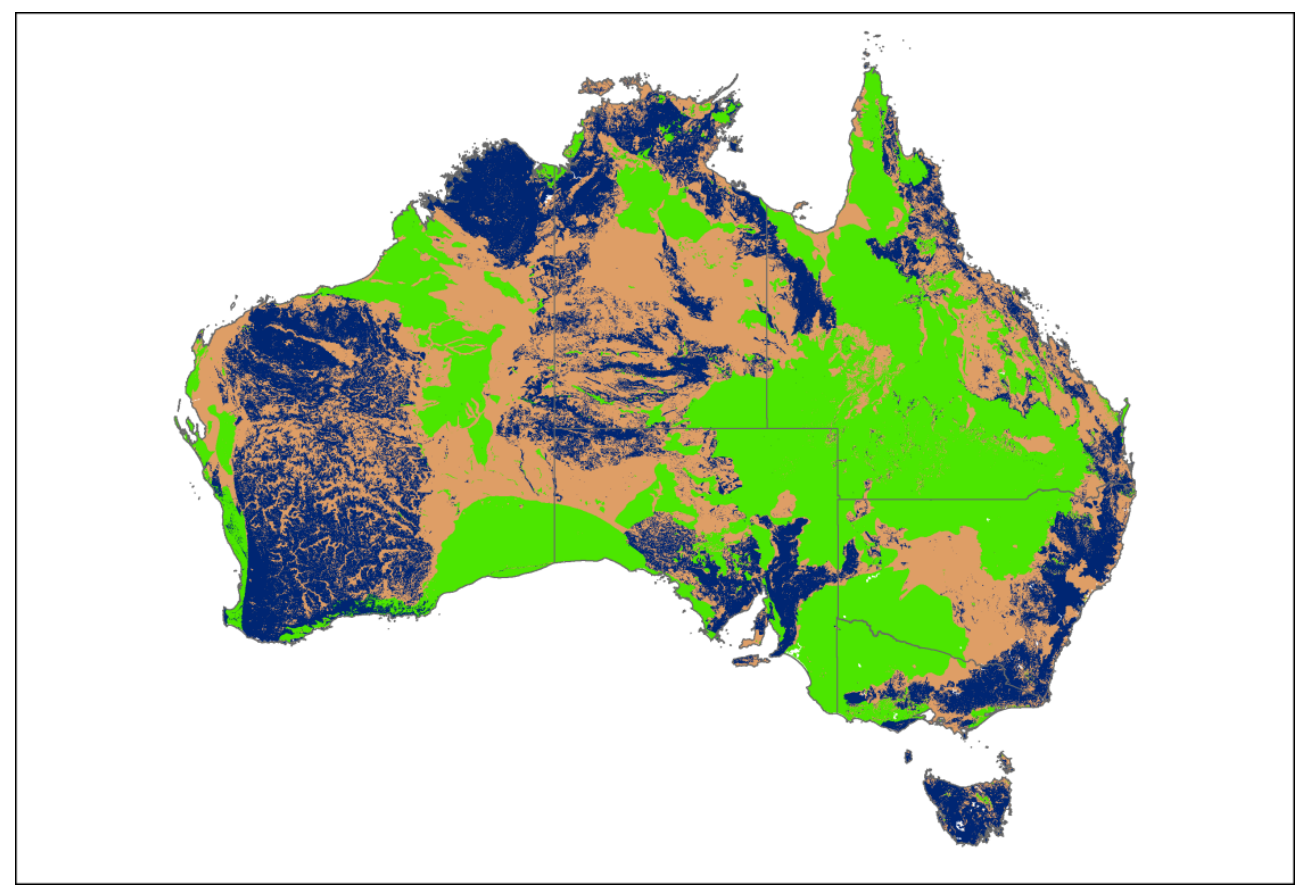

Figure 2. Groundwater flow systems (Coram et al., 2000). Blue represents local GFS, orange represents intermediate GFS and green represents regional GFS.

\subsection{River losses to groundwater}

River losses to groundwater have been allowed for in the AWRA-R model and there are tools within Source Rivers (GW-Link) designed specifically for this task.

AWRA-R is a node-link river routing model, which means that it is not spatially explicit. In river reaches that are identified as losing water to the groundwater store there is no straight 1:1 mapping this back to AWRA grid cells. The volume of water lost from the river will need to be disaggregated back to individual AWRA grid cells, in the absence of any better information this is likely to be averaged between cells so that all cells within a river reach get apportioned the same amount of river leakage. Groundwater level mapping may help to identify which cells within a river reach are gaining and losing but this information is unlikely to be available everywhere.

\subsection{Recharge from overbank flooding}

In some very detailed modeling with HydroGeoSphere, Doble et al (2011) set up some numerical experiments to investigate the process of groundwater recharge from overbank flooding. The results of this modeling were then simplified down to a level suitable for use in AWRA-G. It was found that overbank recharge could be approximated by:

$$
\mathrm{R}=\min (\mathrm{I}, \Delta \mathrm{S}+\mathrm{Q})
$$

where $\mathrm{R}$ is recharge, $\mathrm{I}$ is potential infiltration, $\Delta \mathrm{S}$ is the potential change in storage and $\mathrm{Q}$ is the potential lateral flow away from the area of inundation. These quantities can all be estimated nationally. The potential infiltration is dependent upon surface soil of the floodplain and the extent, depth and duration of the flood. The potential change in storage is dependent upon the depth to water table, specific yield of the soil/aquifer and the extent of flooding. The potential discharge away from the area of inundation is dependent upon the transmissivity of the aquifer, duration and extent of flooding and the depth of the water table.

The extent, duration and depth of flooding will be provided by the open water likelihood mapping (Gouweleeuw et al., 2011; Guerschman et al., 2008). This work comes from the analysis of MODIS imagery; therefore it is available at a frequency of 8 days at a resolution of $500 \mathrm{~m}$.

This work also relies upon a water table map as described in 3.2. However the spatial resolution will be different as it will be required to match the resolution of the MODIS imagery. The recharge from overbank flooding will be calculated at a resolution that is finer than the AWRA grid and will then be aggregated up to the $0.05^{\circ}$ grid for passing onto AWRA-L. 


\subsection{Discharge to the ocean}

Groundwater discharge to the ocean will be accounted for in the same manner as the lateral flow is calculated (see 3.2) for every AWRA grid cell that shares a boundary with the coast. The hydraulic gradient will be estimated from the difference in groundwater level between the AWRA grid cell and an assumed 0 mAHD for sea level. If the groundwater level within the grid cell is below sea level then sea water intrusion can be calculated as the reverse of discharge to the ocean. Density effects are too complicated to be considered in a model of this scale.

\subsection{Interactions with deep confined systems}

Some confined aquifer systems have very little interaction with the surface and so can be treated in a much simpler fashion than other aquifers that have extensive interactions with the surface. One such example is the Great Artesian Basin (GAB). The GAB has flow paths of over $1000 \mathrm{~km}$ and residence times of over a million years. For the majority of these flow paths the water is deep underground and has no interaction with the surface. These parts of the aquifer are of little interest in the AWRA model. The groundwater store within AWRA-L is only a single layer; there is no mechanism to pass water through a grid cell without it interacting with the other elements of the water cycle. In these situations it is proposed to not model the lateral flow in these aquifers but only add in the fluxes where they interact with the surface (if these fluxes are known). For the GAB, the intake beds have been mapped and the recharge to the deeper layers can be treated the same as pumping by extracting water from the groundwater store in AWRA-L, this will be a prescribed flux that is calculated independently and then applied in each AWRA grid cell.

It will require some thought as to which aquifers are treated in this way and which aquifers are treated as a single layer system. For example, pumping from the Calivil Formation in the Murray Basin will induce leakage from the overlying Shepparton Formation, in this instance the confined aquifer is having an impact on the surficial aquifer and so cannot be excluded from the modeling.

\section{CONCLUSIONS}

This paper has described the conceptualisation for a groundwater component model for coupling to an existing land surface model. This model will provide improvements to the reporting of water balance fluxes and stores for the Bureau of Meteorology's National Water Accounts and Water Resource Assessments into the future.

\section{ACKNOWLEDGMENTS}

This work is part of the water information research and development alliance between CSIRO's Water for a Healthy Country Flagship and the Bureau of Meteorology.

\section{REFERENCES}

Coram, J.E., Dyson, P.R., Houlder, P.A. and Evans, W.R., 2000. Australian groundwater flow systems contributing to dryland salinity. Project Report for the National Land and Water Resources Audit., Bureau of Rural Sciences, Canberra.

Crosbie, R.S. et al., 2008. Development of a national groundwater resources assessment technology: Discussion paper prepared for the Bureau of Meteorology, CSIRO: Water for a Healthy Country National Research Flagship.

Doble, R.C., Smerdon, B.D., Peeters, L., Cook, F. and Crosbie, R.S., 2011. Aquifer recharge from overbank floods. submitted to Water Resources Research.

Fan, Y. and Miguez-Macho, G., 2011. A simple hydrologic framework for simulating wetlands in climate and earth system models. Climate Dynamics, 37(1-2): 253-278.

Frost, A., Lerat, J., Srikanathan, S. and Stenson, M., 2011. AWRA River System Modelling Requirements and Implementation, Bureau of Meteorology, Sydney.

Gouweleeuw, B., Ticehurst, C. and Thew, P., 2011. Surface water volume estimation in support of water accounting, CSIRO: Water for a Healthy Country National Research Flagship.

Guerschman, J.P. et al., 2008. Actual evapotranspiration and water balance estimates from satellite observations over the Murray-Darling Basin, CSIRO: Water for a Healthy Country National Research Flagship.

Gulden, L.E. et al., 2007. Improving land-surface model hydrology: Is an explicit aquifer model better than a deeper soil profile? Geophys. Res. Lett., 34(9): L09402.

Kowalczyk, E.A. et al., 2006. The CSIRO atmosphere biosphere land exchange (CABLE) model for use in climate models and as an offline model, CSIRO Marine and Atmospheric Research paper 013. 
Crosbie et al., AWRA-G: A groundwater component for a continental scale land surface model

Leighton, B., Lerat, J. and Stenson, M., 2011. AWRA and Source Integration: Purpose, Requirements and Data Exchanges, CSIRO: Water for a Healthy Country National Research Flagship.

Liang, X., Xie, Z. and Huang, M., 2003. A new parameterization for surface and groundwater interactions and its impact on water budgets with the variable infiltration capacity (VIC) land surface model. J. Geophys. Res., 108(D16): 8613.

Maxwell, R.M. and Kollet, S.J., 2008. Interdependence of groundwater dynamics and land-energy feedbacks under climate change. Nature Geosci, 1(10): 665-669.

Oleson, K.W. et al., 2010. Technical description of version 4.0 of the Community Land Model (CLM), NCAR Technical Note NCAR/TN-478+STR, Boulder, CO.

Peeters, L., Crosbie, R. and van Dijk, A.I.J., 2011. Incorporating groundwater dynamics and clay content in AWRA-L, CSIRO: Water for a Healthy Country National Research Flagship.

Rassam, D.W., 2011. A conceptual framework for incorporating surface-groundwater interactions into a river operation-planning model. Environmental Modelling \& Software, in press.

van Dijk, A.I.J.M., 2010. The Australian Water Resources Assessment system. Technical report 3. Landscape model (version 0.5) technical description, CSIRO: Water for a Healthy Country National Research Flagship.

Welsh, W.D. et al., 2011. An integrated modelling framework for regulated river systems. Environmental Modelling \& Software, in press. 